\title{
台風通過に伴う中海の水位変動と それが中海の水環境に及ぼす影響 \\ WATER LEVEL FLUCTUATION CAUSED BY TYPHOON IN LAKE NAKAUMI AND ITS EFFECTS ON WATER ENVIRONMENT
}

\author{
福岡捷二 ${ }^{1}$ ，上原浩 ${ }^{2}$, 黒川岳司 ${ }^{3}$, 鈴木篤 $^{4}$, 肥田幸子 ${ }^{5}$ \\ Shoji FUKUOKA, Hiroshi UEHARA, Takeshi KUROKAWA, Atsushi SUZUKI, Sachiko HIDA

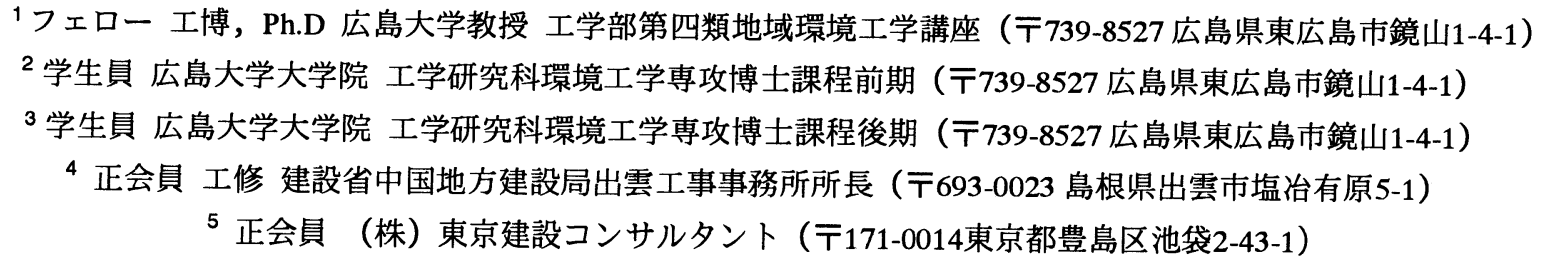

The water level in the Lake Nakaumi is predominated by that of the Japan Sea, and is affected not only by tide but also by meteorological factors. In this paper, we have studied effects on water environment of the Lake Nakaumi by typhoons: Firstly, we have classified the typhoons according to the tracks following toward Japan and have shown the water level fluctuations in the Lake Nakaumi while typhoons pass Japan. Secondaly, we have evaluated the water exchange while typhoon9719 has passed near the Lake Nakaumi. This study shows four types of typhoons depending on their tracks The water levels in the Lake Nakaumi are effected by the type of typhoon. It is also observed that the volume of water exchange by the typhoon9719 in Lake Nakaumi is nine times as large as that of during ordinary condition.

Key Words : Lake Nakaumi, Typhoon, Water Level, Wind, Water Exchange

\section{1. 序論}

山陰地方のほぼ中央, 日本海沿岸に面して東西に並ん で存在する中海, 穴道湖では水産資源が豊富であり, 周 辺住民の生活の糧となっている. しかし，近年における 中海, 穴道湖の水質悪化は水域に住む生物の生息環境を 悪化させている. アオコや赤潮の発生は悪臭を放ち, 景 観を損なうなど水環境を大きく低下させる.このような 事態を解決するために早急な水質改善が求められてい る. 著者ら゙はこれまで中海における流動, 水質の現地観 測を行い，潮汐や気象作用を外力とする様々な条件下で の流れ場を明らかにしてきた. しかし，それらは観測を 行つた時に生じていた流れ場に関する考察であって, 観 測が行われていない時の流れ場はどのようなものかを説 明するまでに至っていない. 本研究ではこのことを検討 するために中海, 穴道湖の流れと日本海の水位変動の関 係を外力条件から検討していく.
中海, 穴道湖は日本海と連結しているため, 日々の潮 汐による日本海の水位変動の影響を受けるが, 気象変化 の影響も大きく受けることが分かっている゙. 気象変化に 伴う日本海の水位変動は, 気圧配置を考虑に入れた日本 周辺の気象場から考える必要がある. 気象変化の代表と して台風が挙げられる. 台風は数日〜週の時間スケール で日本海の水位を変化させる.この水位変化により生じ る流れの影響は中海全体に及ぶだけでなく，宫道湖にま で達する. さらに，台風は強風を数日にわたつて継続さ せ, 降雨をもたらす.このように台風は複数の強い外力 を伴うため，中海，穴道湖の流れ場を明らかにするに は，まず台風通過に伴う水位変動を明らかにする必要が ある.

本研究では，まず台風の移動経路を考虑に入れて台風 を分類し，その結果と日本海の水位変動の関係を明らか にする. そして, 台風通過時の中海, 穴道湖における水 位変動と水交換, 水質変化について検討し, 台風が中 海, 穴道湖の水環境に与える影響を評価する。 


\section{2. 台風が美保関の水位変動に及ぼす影響}

\section{（1）中海，穴道湖の地形特性}

図-1に中海, 穴道湖周辺の概略を示す. 中海, 穴道湖 は斐伊川水系であり，突道湖は大橋川(幅 $200 \mathrm{~m} ，$ 長さ $7.6 \mathrm{~km}$ )を通じて中海と，中海は境水道(幅 $400 \mathrm{~m}$ ，長さ $8.7 \mathrm{~km})$ を通じて日本海と連結している. 大橋川，境水道 の規模はともに中海(水面積 $80 \mathrm{~km}^{2}$ )，突道湖(同 $80.3 \mathrm{~km}^{2}$ ) に比べ小さい.このため, 日本海の水位変化は中海, 穴 道湖と時間的に遅れて伝播する。 その遅れは美保関水位 に対し中海が2〜3時間, 穴道湖が7〜8時間である1).

日本海は太平洋, 東シナ海と 4 つの狭い海峡（対馬海 峡, 津軽海峡, 宗谷海峡, 間宮海峡) で連結されてい る.これによって，日本海の水位は気圧変化や風などの 外力が加えられたとき太平洋側とは異なる応答を示す。 台風の接近は急激な気圧変化や強風をもたらすが，水位 と気压の関係は個々の台風の特性によって異なってく る. 特に, 台風の移動経路によって日本海の水位変動は 様々な形態をとる ${ }^{3}$ 。そこで，まず台風の接近に伴う日本 海（美保関）の水位変動を台風の移動経路や速度等の特 性を考慮に入れて，分類，検討する.

\section{（2）台風通過に伴う美保関の水位変動}

台風は一般に夏〜秋にかけて多く日本に接近する．日 本に接近する台風の強さや大きさ，移動経路は多種多様 である. まず過去の台風の移動経路を調べ，分類し，こ れらと美保関の水位変動の関係を検討する.

\section{a）台風の移動経路の分類}

通常, 台風は北緯 $10 \sim 20^{\circ}$ 付近の太平洋上で発生す る. その後北上して日本に接近し，そのうち年に2〜3個 上陸する. 台風の移動経路は季節によって特徵がある. ここでは1990〜1997年の8年間，日本に影響を及ぼした 台風について移動経路と美保関の水位変動の関係を調心゙ た4)。この間，台風は48個日本に接近した. 図-2に示すよ うに類似した移動経路や水位変動を起こす台風について まとめると，4種類に分類することができる. 移動経路， 美保関での水位と気圧変化，中海での風向風速などを分 類の基準とし，類似したものを同一分類に入れている. これらの中で美保関の水位変動に大きな影響を与えてい る台風はType1とType2であると考えられる. Type1は日 本海を南西から北東へ進む経路, Type2は日本の南から 接近し，上陸する経路である.

\section{b）台風の経路か门ype1の場合の美保関の水位変動}

Type1の経路は, 太平洋高気圧の発達する夏の時期に 多く，太平洋高気圧の外縁を台風が進むとき，この経路 をとりやすい.このときの水位変動を1994年29号台風(以 後9429号と記す)を例に考察する. 図-3に9429号の移動経 路と(a)深浦，(b)美保関，(c)長崎の水位と気圧，(d)中海 での風向風速の経時変化を示す. 水位は 25 時間で移動平

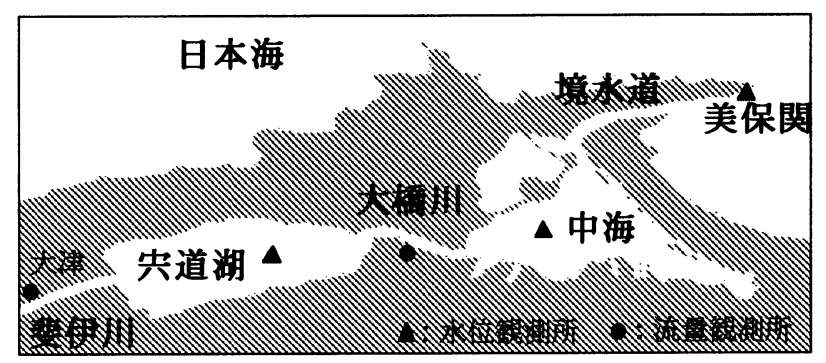

図-1 中海, 宾道湖周辺概略

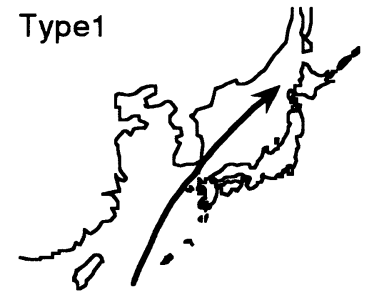

日本海を南西から北東 几移動

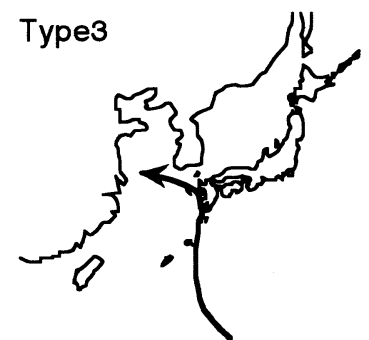

日本の南から接近す るが逸れていく

図-2台風の移動経路分類

1990〜97年に日本に接近した48個の台風から

均された值である.台風がType1の経路をとるとき全観 測点で水位は上昇する. その上昇量は大きく，美保関で 約 $40 \mathrm{~cm}$ であった. また，美保関において気圧低下ピーク 時と水位上昇ピーク時にタイムラグがあることが分か る. 9429号ではそれは約12時間であった.この理由を磯 崎”は日本海入り口において外力が与えられ，山陰沿岸の 陸棚地形から陸棚波が発生し，それが山陰沿岸を伝播す るためであると考察している. その伝播速度は $3.4 \mathrm{~m} / \mathrm{s}=$ $122 \mathrm{~km} / \mathrm{h}$ )で，これは台風(約 $40 \sim 60 \mathrm{~km} / \mathrm{h})$ よりも遅いため に気圧低下ピーク(台風最接近時)よりも水位上昇ピークが 遅れるのである. また，長崎，深浦では気圧低下ピーク とほぼ同時刻に水位上昇ピークが生じている.このこと から美保関が位置する山陰沿岸地域の水位変化は他の日 本海沿岸地域とは異なる変化をすることが分かる.

このように美保関で水位が上昇することはType1の経 路をとるときほぼ同様であつたが，この経路を通つたに も関わらず異なる水位変化をする場合があつた. 図-4は 9113号時のものである. 経路は9429号と同様に日本海を 通つているが，台風接近時に美保関，深浦では水位が大 きく低下している.これに対し，長崎では大きな水位変 化はない.ここで，9429号と9113号の風向風速を比較し 


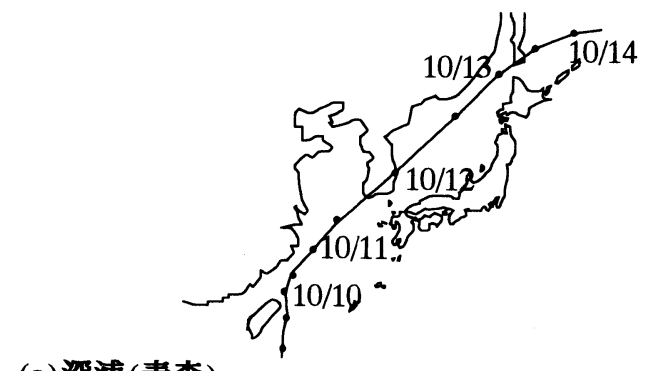

(a)深浦 (青森)

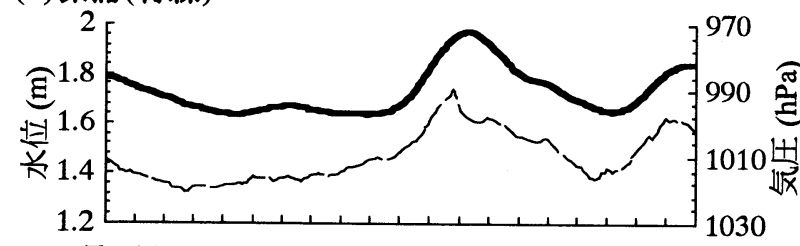

10月 7日 10 月 9日 10 月 12 日 10 月 14 日

(b)美保関 (島根)

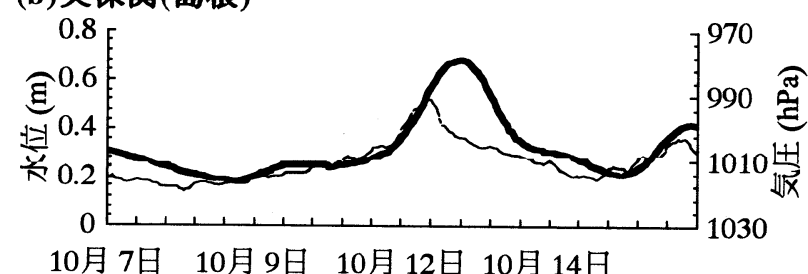

10月 7日 10 月 9日 10 月 12 日 10 月 14日

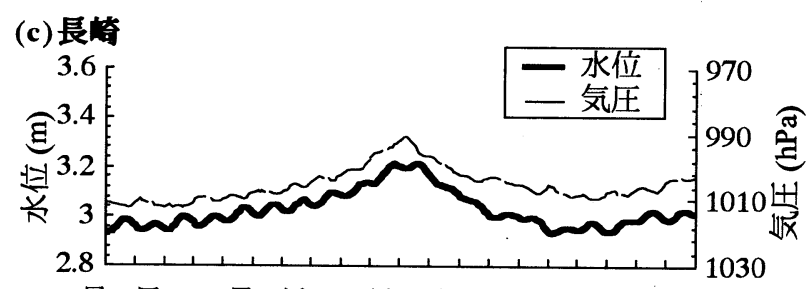

10月 7日 10 月 9日 10 月 12 日 10 月 14 日

(d)風向風速

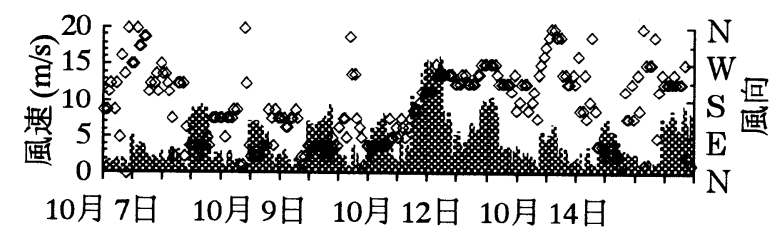

図-3 台風9429号の移動経路，および日本海 の水位, 中海の風向風速の経時変化 1994年10月7日～10月16日(Type1)

てみると，9429号時は最大風速が $15 \mathrm{~m} / \mathrm{s}$ の西風，一方， 9113号時は $10 \mathrm{~m} / \mathrm{s}$ 以上の北東風が約 1 日間吹き続けてい る. その強風によって日本海では南西向きに流れが生 じ，これにコリオリカの作用が加わって山陰沿岸から離 れる向きに海水流動が生じるため美保関では水位が低下 したと考えられる゙.99113号時にこのような強い東風が吹 き続けた理由は9429号が九州の南西から移動する場合と 異なり, 九州の南から北上して来るためである.このよ うに台風が日本海を通る場合でも，日本に接近するとき の経路によって風速，風向が異なり，日本海ではそれに 応じた海水流動が生じるため, 美保関水位変化の形態が 異なってくる. Type1は1990〜1997年の間の48個のうち 9個あったが, 水位が低下するケースは2個あった.

次に，水位が低下する特別な場合を除き，一般的な Type1の台風通過により水位上昇する台風について気圧 (a)深浦 (青森)
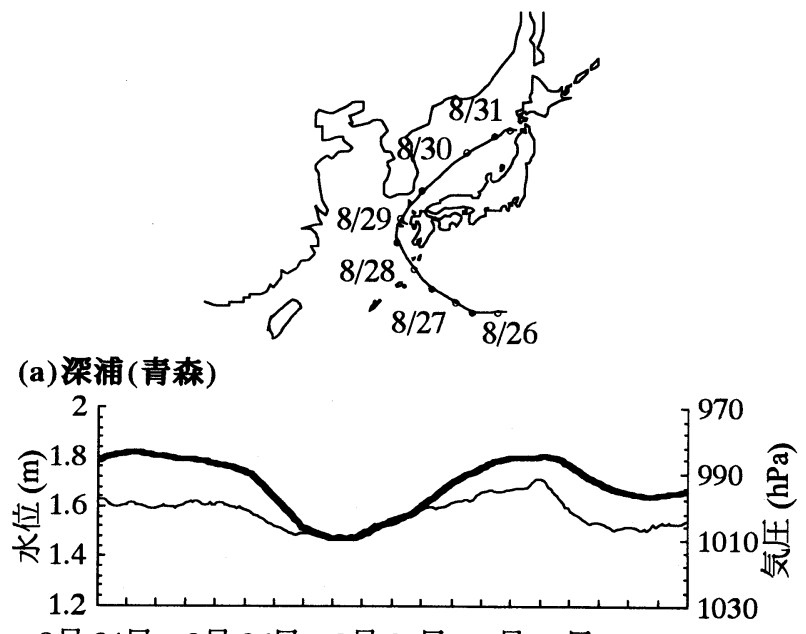

8 月 24 日 8 月 26 日 8 月 29 日 8 月 31 日

(b) 美保関 (島根)

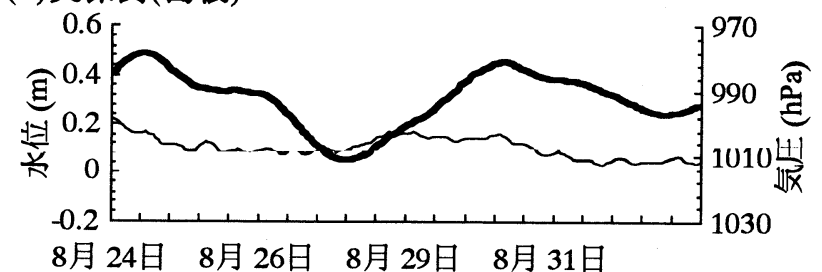

(c) 長崎

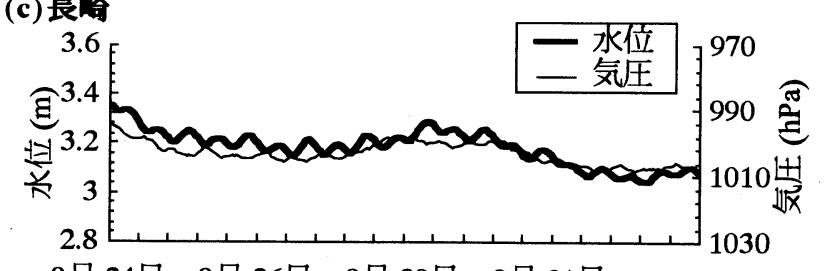

8月 24日 8月 26日 8 月 29日 8 月 31日

\section{(d)風向風速}

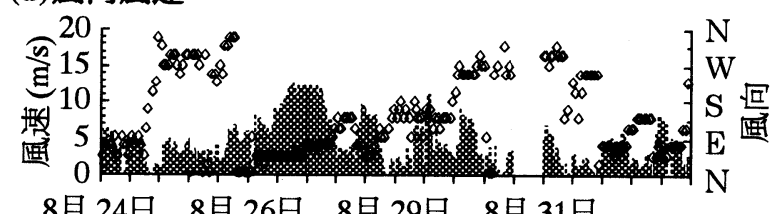

8 月 24 日 8 月 26 日 8 月 29 日 8 月 31日

図-4 台風9113号の移動経路，および日本海 の水位, 中海の風向風速の経時変化 1991年8月24日 9月2日(Type1)

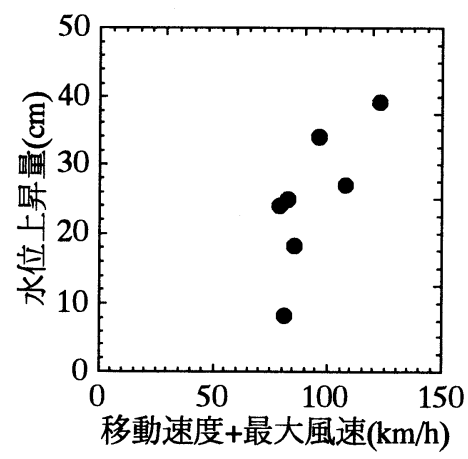

図-5 台風の移動速度と最大風速の和と 水位上昇量の関係(Type1)

低下, 他の外力要因との関係について考察する. 水位上 昇は陸棚波の伝播によるものと考えられていることか ら，陸棚波はどのような外力要因によって発生するかを 考えてみる. 外力要因には気圧, 風, そして台風の移動 
(a) 美保阅水位と気压
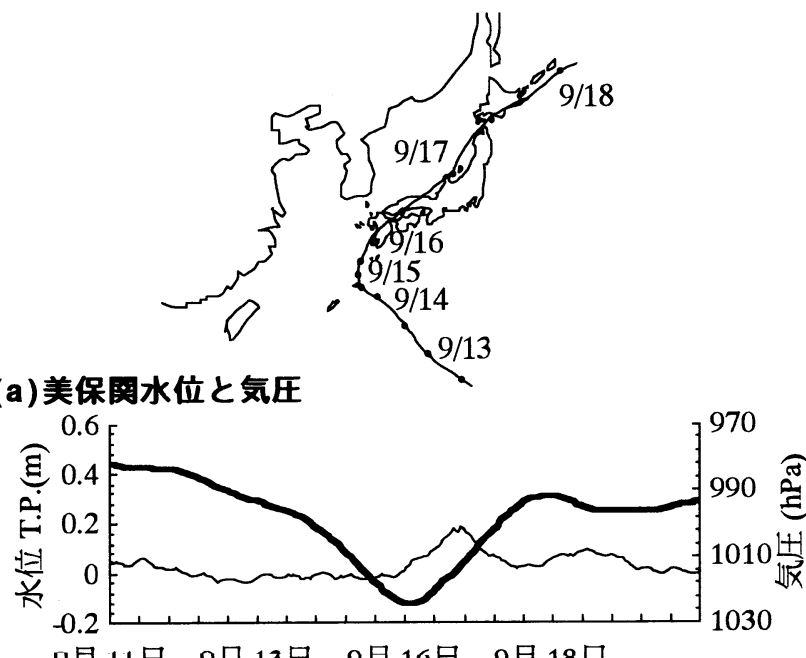

9月11日 9 月 13 日 9 月 16 日 9 月 18 口

\section{(b)圂向風速}

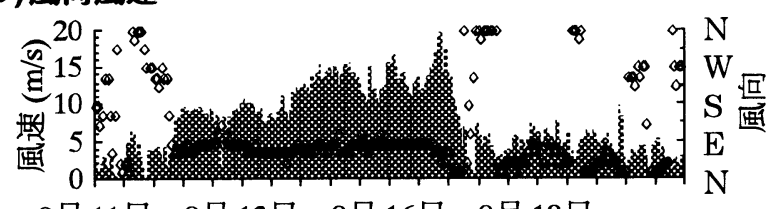

9月 11 日 9 月 13 日 9 月 16 日 9 月 18 日

図-6 台風9719号の移動経路，および美保関 の水位, 中海の風向風速の経時変化 1997年9月11日～9月20日(Type2)

速度が挙げられる.これらの関係を図-5に示す。横軸は 台風の速度に中心付近の最大風速を加えたものである. この理由は台風の日本海進行時には, 気圧低下による海 面の吸い上げの他に，台風の移動に加えて風により海水 流動が生じるためと考えられる.これら2つには強い相関 があり, 台風がType1の経路をとるときの美保関での水 位上昇量は気圷低下に加え, 台風の移動速度と最大風速 が支配的であると考えられる。

c）台風の経路か十ype2，3の場合の美保関の水位変動

9719号を例に考察する. 図-6に移動経路と(a)美保関の 水位と気圧，(b)中海での風向風速の経時変化を示す. 期 間前半, 台風接近につれ気圧変化は小さいが水位は大き く低下し, 台風通過後水位は上昇する. 経路がType2の とき, 美保関では気圧変化によらない水位変化をする. これは前述の9113号時の水位変化と同様である. 9719号 時の風向風速を見ると，9113号時と同様に強い東風が数 日間吹き続いている.このように台風接近時に美保関で 水位が低下するのは, 移動経路が若干異なっても台風が 日本の南から接近し，日本海に強い東風が吹き続けたと きであると考えられる. また, Type3の場合の美保関の 水位変動について, 強い東風が吹き続けたならば, Type2と同様に水位の低下が見られた。

\section{d）台風の経路がype4の場合の美保関の水位変動}

Type4の台風は18個あったが, 日本海から遠く離れて いるため，美保関の水位変化に明確な台風の影響は見ら れない.しかし，この経路の場合にも美保関の水位が低 下した台風が3個あった. 図-7は9512号時のもので，台風 は中海から遠く離れているにも関わらず美保関の水位は (a)美保閣水位と気圧
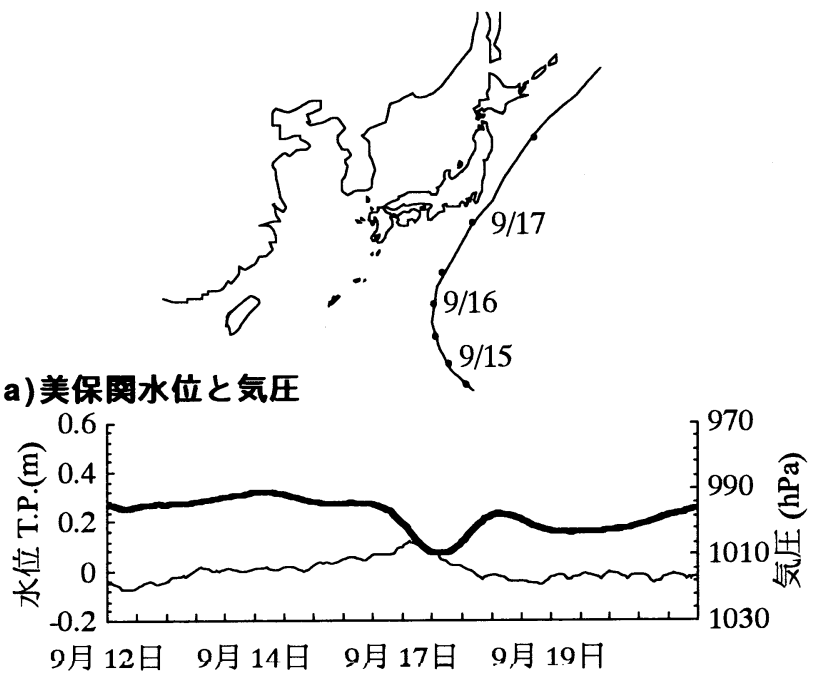

(b)屈向圂速

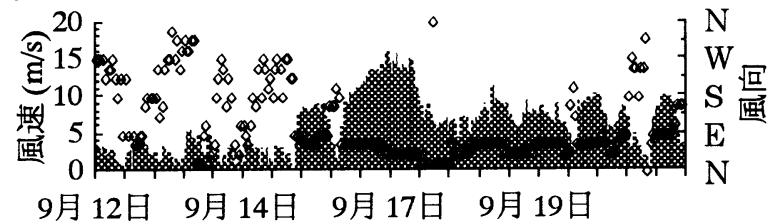

图-7 台風9512号の移動経路，および美保関 の水位, 中海の風向風速の経時変化 1995年9月12日～9月21日(Type4)

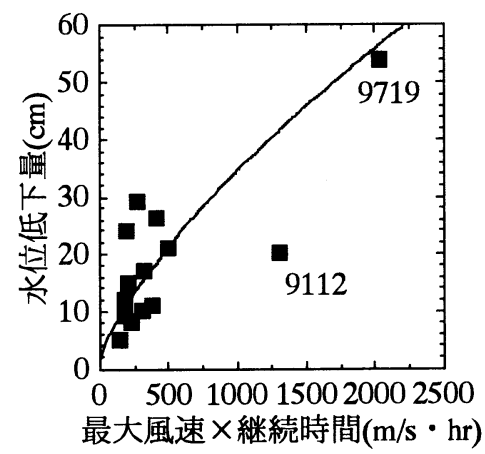

図-8 台風の最大風速と継続時間の積と 美保関水位低下量の関係

低下している. 風向風速を見るとType2と同様, $10 \mathrm{~m} / \mathrm{s}$ 以 上の強い北東風が吹き続けている.このことからも台風 接近に伴う強い東風が吹き続けることによって日本海で は海水流動が生じ, 美保関の水位を低下させることが分 かる. 経路がType4の場合, 美保関水位はほとんど台風 の影響を受けないが，日本海で強い東風が吹き続ければ 水位低下が生じる場合がある.

ここで, 台風接近時の美保関水位の低下と東風の強さ の関係について調べた. 中海での風向風速から各台風の 最大風速と台風の影響と思われる強い東風の継続時間を 調べ，それらの積と美保関の水位低下量の関係をプロッ トしたものか泪-8である.この図から, 最大風速と継続 時間の積は美保関の水位低下量に関係していると思われ る. 9112号が外れているのは，移動経路が異なっていた （Type3）ためと考えられる.これらから台風接近時に 美保関で水位が低下するのは台風の移動経路に加え, 東 風の強さと継続持間が效いていることが分かる. 


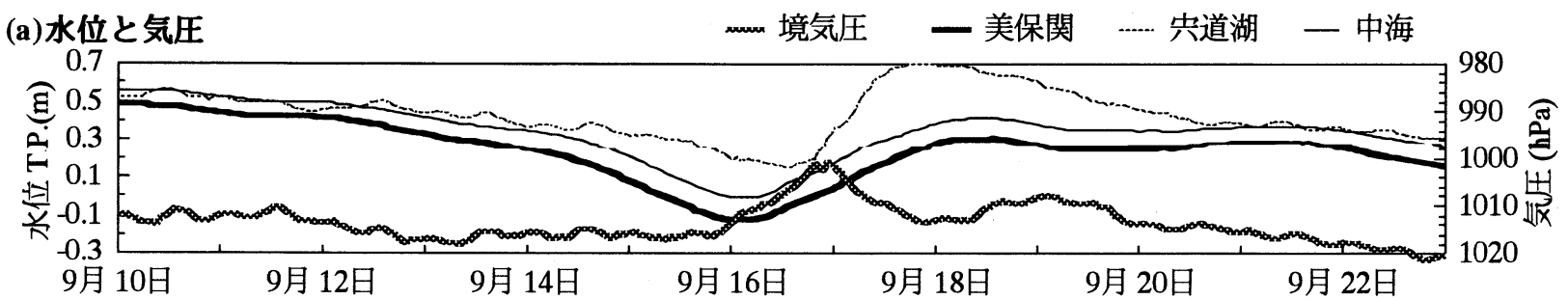

(b)斐伊川流量と降雨量

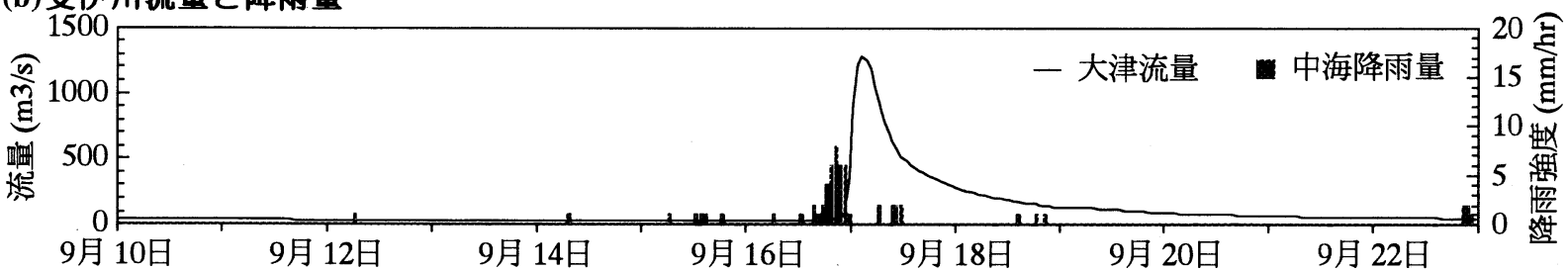

(c)中海, 美保関の水位差と大㭏川流量

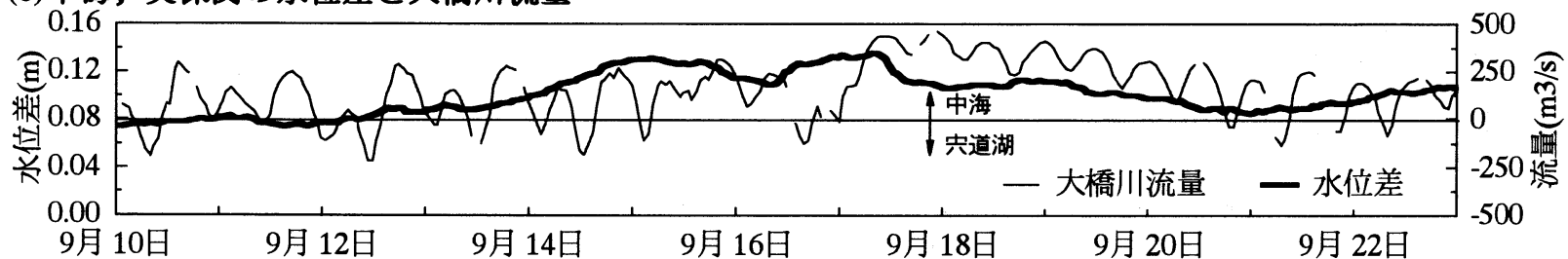

(d) 水温

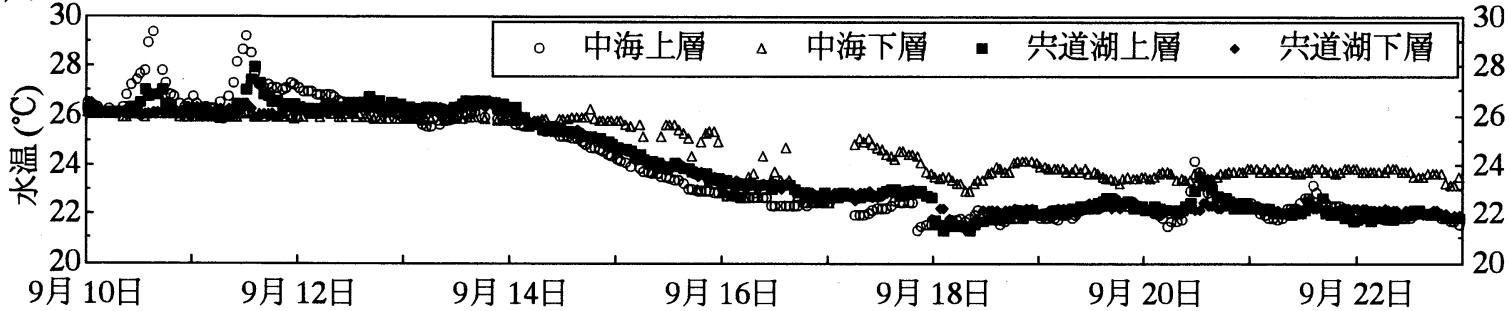

(e)塩分摆度

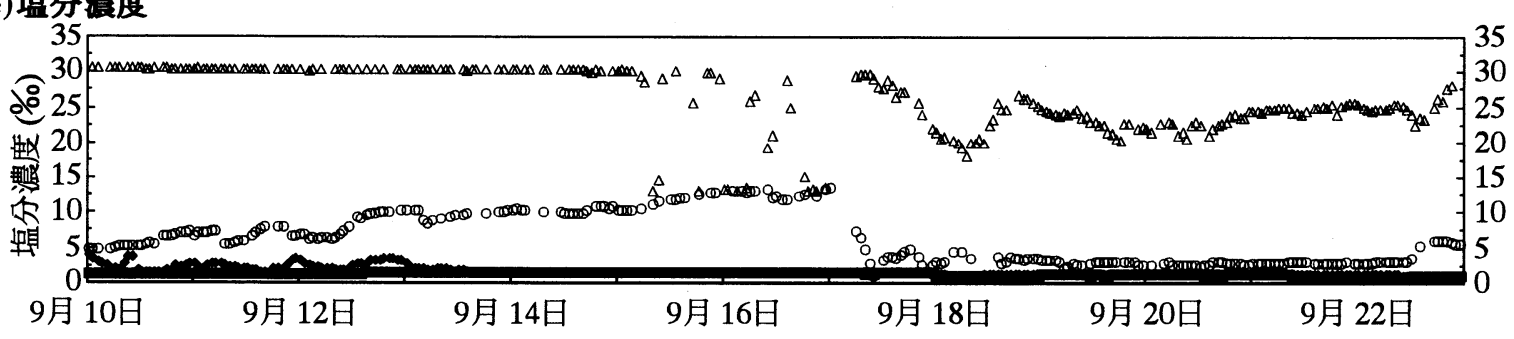

図-99719号通過時の水位と気圧，斐伊川流量と降雨量，中海一美保関の水位差と 大橋川流量, および中海, 宾道湖の水温と塩分濃度の経時変化

1997年9月10日～9月22日

3. 台風9719号の通過に伴う中海, 宍道湖の水位 変動と水環境の変化

中海, 穴道湖は斐伊川から淡水, 日本海から海水の流 入を受けている.これらは水域の水環境にとって重要な 要素であり，流動場とともに水質場を決める．台風通過 時には大規模な水位変動，降雨による河川流量の増加が 見込まれ，各水域の水交換が促進される.これは水域の 水質変化をもたらし，水質管理上，重要な情報である。 ここでは, 台風9719号がもたらした中海, 穴道湖の水環 境の変化について検討する.

（1）日本海と中海, 穴道湖の水位変動

図-9は9719号通過時の(a)美保関，中海，突道湖の水位 と境港の気圧，(b)斐伊川流量(大津観測所)と中海湖心降 雨量, (c)中海, 美保関の水位差と大橋川流量, (d)水温, (e)塩分濃度の経時変化である. 9719号の経路はType2で あり, 強い東風力吹き続ける(図-6(b))ため美保関水位は 低下する. 9719号が属するType2は日本に接近する台風 の中で比較的頻度が高く，中海ではよく起こる現象であ る.9/14から美保関水位の低下に追随して中海，宾道湖 の水位が低下する. しかし穴道湖では日本海水位変動の 伝播が遅いため, 宾道湖と中海で徐々に水位差が生じ, 9/15以降大橋川を介して穴道湖の水は中海へ流れる. そ の後9/16に台風が最接近し，降雨をもたらした結果，斐 伊川流量が増加する.これにより突道湖水位が上昇し， 9/16〜20にかけて中海水位占り常に高い状態か続き，大 橋川を通じて水が中海へ大規模に流れ込む.このとき中 海と美保関の水位差が台風接近前の $8 \mathrm{~cm}$ から $12 \mathrm{~cm}$ になる 
ことから，穴道湖からの洪水流入が中海水位を上昇させ たことが分かる. しかし，その上昇量 $(4 \mathrm{~cm})$ は美保関(約 $40 \mathrm{~cm})$ に比べて小さく，中海水位は以前の美保関水位の 低下から上昇への変化に追随している. 中海水位は平常 時はもとより2)，河川洪水時においても日本海の水位変化 に支配されている.

\section{（2）中海，穴道湖における水交換}

次に，9719号時における中海，窔道湖の水交換につい て, 河川や外海加の流出入, 降雨量から考察する.こ こでは現象を簡単に捉えて，中海，穴道湖は完全混合の 水域と考え，中海には河川と日本海の両方から流入，宍 道湖は河川流入のみとする. 交換率をパラメータとして 用い，中海，宾道湖の水環境に与える台風の影響を評価 する. 交換率は次式で表される.

$$
\alpha=\mathrm{Q} / \mathrm{V}
$$

$\mathrm{Q}$ : 総流入量 $\left(\mathrm{m}^{3}\right), \mathrm{V}$ : 総水容量 $\left(\mathrm{m}^{3}\right)$ である. 斐伊川の平 均年流入量は $1.26 \times 10^{9} \mathrm{~m}^{3}$, 中海, 宍道湖の総水容量は $4.37 \times 10^{8} \mathrm{~m}^{3}, 3.66 \times 10^{8} \mathrm{~m}^{3}$ であり, 各々の年平均交換率 は $\alpha_{\text {中 }}=2.89, \alpha_{\text {穴 }}=3.45$ となり, 中海, 突道湖では 4 ケ 月，3.5ケ月で交換が行われている.ここで，9719号通過 時の河川流入量と降雨量, 外海水流入量から, 9719号の 交換率を求める. 図-9から台風通過期間(9/16〜19)の河川 流入量と降雨量から中海, 穴道湖への流入量を, 9/16〜 9/18の中海水位上昇期に外海から中海へ流入した外海水

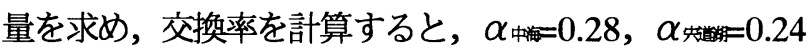
となる. また，台風通過のない平常時(潮汐を考えず河川 流入のみ) 4 日間の交換率は， $\alpha_{\text {中 }}=0.03 ， \alpha_{\text {究 }} 0.04$ であ る. 9719号時と平常時を比較すると, 9719号時の方が平 常時より各々約9倍，6倍大きい. 1個の台風通過4日間で の交換量は, 平常時の約1ヶ月分に相当する.

\section{（3）中海, 穴道湖における水質の変化}

ここでは9719号通過時の中海, 穴道湖における水質変 化について検討する. 図-9より9/12まで気圧変化が小さ く気象状態は安定しているため, 中海, 穴道湖の水温, 塩分濃度の変化は小さい。中海では上下層の塩分濃度差 が大きく，強固な密度躍層が形成されている．9/14以 降，台風による強い東風のため中海では混合が生じ，上 層塩分濃度が上昇するか下下層はほとんど変化しない. 台 風通過後, 河川流量の増大により中海, 穴道湖で水温が 低下し, 最終的に中海では水温は上層で約 $4^{\circ} \mathrm{C}$, 下層で約 $3^{\circ} \mathrm{C}$ 低下している. 穴道湖でも両層ともに $4^{\circ} \mathrm{C}$ 低下した。 また，中海では大橋川の中海への流入量が増加した9/17 〜9/18の1日間で上下層ともに塩分濃度が約10\%低下して いる. その後, 台風最接近時の9/17から美保関水位, 河 川流量, 各水域の水位関係など台風がもたらした影響が なくなり，それらが通常状態に戻る9/21まで約5日間かか っている. しかし, 水温や塩分濃度といった湖内水質状
態は台風通過から1週間経った9/23においても台風接近以 前の状態には戻らず，新たな水質場が形成されている。

以上のように, 台風の通過が中海, 穴道湖の水環境に 及ぼす影響は大きい。 また台風は夏〜秋にかけて通過す ることが多いため，この時期における水域の水質場を考 える場合，重要な外力要因であると考えられる.

\section{4. 結論}

本研究では日本に接近する台風を移動経路について分 類し，それと中海の水位変動の関係について考察した. さらに，台風通過時の中海の水位変動と水質変化，水交 換について検討した。これらによって次のような知見を 得ることができた。

（1）日本に接近する台風は，移動経路について4種類に 分類できる.これらが美保関の水位に与える影響は各々 異なり，その中でも経路Type1とType2の台風が美保関水 位に大きな影響を与えている.

（2）台風がType1の経路をとるとき，美保関の水位は 上昇する．その水位上昇量は台風が日本海に侵入すると きの台風の移動速度と風速に関係する. しかし, 台風が 日本の南から接近すると, 日本海での風系が異なるた め, 美保関では水位が低下する場合がある.

（3）Type2の経路をとると，台風接近時に美保関では 水位が低下する.これは, 台風が日本の南から接近する ため日本海では強い東風が吹き続け，海水流動が生じる ことが原因である．そして，美保関の水位低下量は東風 の強さと継続時間により決まる.

（4）台風通過による中海, 窔道湖の水交換, 水質変化 について，日本に接近する頻度の高い経路である9719号 を例として検討した. 台風通過時の4日間の中海, 共道湖 の水交換率は各々 $0.28,0.24$ であり，通常時の0.03， 0.04に比べ約9倍，6倍大きい. これは平常時の1ヶ月分の 交換量に相当する. また，台風通過による水温，塩分濃 度の変化は台風通過後1週間経過しても台風通過以前の状 態に戻らず，新たな水質場を形成する. 夏〜秋にかけて の台風の通過は中海の水環境の変化を考える上で, 重要 な外力要因として扱う必要がある.

\section{参考文献}

1)福岡捷二, 黒川岳司, 日比野忠史, 鈴木篤, 中村剛, 上原 浩: 中海における気象変化に伴う流れと貧酸素水塊の挙動, 土木学会論文集, No.636/V II-13，pp.61-79，1999. 2)日比野忠史 : 連結水系での流動-気候・気象の変化が流れに及 ぼす影響-, 第32回水工学に関する夏期研修会講義集, Aコー ス, pp.A-7-1-20, 1996.

3)Isozaki, I.: An Investigation on the Variations of Sea Level due to Meteorological Disturbances on the Coast of the Japanease Islands (II), Storm surges on the coast of Japan Sea, Journal of the Oceanographical Society of Japan, 24(4), 178-190,1968b.

4)気象年鑑1990年版 1998年版, 気象庁監修, 日本気象協会 編.

(1999.9.30受付) 